\title{
Measurement of anti-DNA antibodies: a reappraisal using five different methods
}

\author{
D A ISENBERG, ${ }^{1}$ C DUDENEY,${ }^{1}$ W WILLIAMS,${ }^{1}$ I ADDISON, ${ }^{2}$ \\ S CHARLES, ${ }^{4}$ J CLARKE, ${ }^{3}$ AND A TODD-POKROPEK ${ }^{3}$
}

From the ${ }^{1}$ Bloomsbury Rheumatology Research Unit, University College Hospital and the Middlesex Hospital; the ${ }^{2}$ Haematology and ${ }^{3}$ Medical Physics Departments, University College Hospital; and ${ }^{4} R I A(U K) \vec{\omega}$ Washington, Tyne and Wear

SUMMARY One hundred and thirty coded sera, 60 from patients with systemic lupus erythematosus (SLE) and 70 from patients with other autoimmune rheumatic diseases were $\stackrel{+}{\circ}$ tested for deoxyribonucleic acid (DNA) binding activity by five different types of assay. These윽 were enzyme linked immunosorbent assay (ELISA) (distinguishing IgG and IgM anti-ssDNAand anti-dsDNA), Crithidia luciliae, a nitrocellulose filter assay, the Amersham kit, and another modified Farr assay, the radioimmunoassay (RIA) (UK). The Crithidia test was the most ${ }^{\oplus}$ specific, none of the controls was positive, but the least sensitive (13\% positive only). The RIA $\vec{\oplus}$ (UK) was the most sensitive (57\% positive). In most of the assays $3-9 \%$ of the controls were. positive. When the SLE sera were analysed according to disease activity the IgG anti-dsDNAD ELISA, all three RIA values, and the Crithidia test values were raised in all the patients with severely active disease. Some patients with inactive disease, however, were positive in each of the tests. The best interassay correlations $(r<0 \cdot 49)$ were found between RIA (UK), and ss IgG and气 the Amersham kit; and between ds IgG and ss IgG. In the main, however, it was clear that different assays are dependent upon distinctive properties of DNA antibodies. It seems inevitable $\overrightarrow{\overrightarrow{0}}$ that most major rheumatology units will require more than one anti-DNA antibody assay. $\exists$

It is now 10 years since an international workshop reported the measurement of anti-DNA antibodies on a set of eight sera by 12 centres in the USA and Europe. ${ }^{1}$ Each centre reported their results using between one and six different methods, and several important points emerged from this meeting. For example, assays using different principles such as the immunofluorescent Crithidia luciliae and Farr assays frequently gave completely different results. Furthermore, even seemingly identical assays, such as the Amersham kit, often gave widely differing results when performed in different centres. Although there was wide agreement on the presence or absence of anti double stranded (ds) DNA antibodies in some of the sera, the report concluded that 'the findings in the different laboratories were dissimilar enough to suggest a need for continued

Accepted for publication 28 January 1987.

Correspondence to Dr D A Isenberg. Bloomsbury Rheumatology Department, Arthur Stanley House, Tottenham Street. London W1P 9PG. caution in interpreting anti-DNA measurements ing various clinical conditions'.

It also became obvious in this study ${ }^{1}$ that preparaê tion of the antigen is important in influencing the results in some assays. Stollar has reviewed thif subject in some detail. ${ }^{2}$ Most obviously, contamina $>$ tion of dsDNA with single stranded (ss) DNA wile seriously interfere with the assay.

In the past 10 years some assays, such as the Crithidia luciliae test, new in 1976, have becoms very popular. In addition, an important technique the enzyme linked immunosorbent assay (ELISA has become increasingly available.

We therefore felt it was time to reappraise the status of anti-DNA assays, especially of those likelyt to be available to practising rheumatologists withino populations of patients they are likely to see. We have approached the problems in a simple, func? tional way by asking which, among a variety o $\vec{g}$ assays now available, are of value in distinguishing systemic lupus erythematosus (SLE) from non-lupuş 
disease and which of these assays reflect disease activity in SLE itself?

\section{Patients, materials, and methods}

\section{PATIENTS}

One hundred and thirty coded sera were prepared having been stored at $-20^{\circ} \mathrm{C}$. Sixty sera from patients with SLE were studied. Each patient fulfilled four or more of the American Rheumatism Association's revised criteria for the classification of disease.$^{3}$ Fifty seven of these patients were female, three male, and their ages ranged between 18 and 66 years. The clinical activity of the patients was assessed by a method published elsewhere ${ }^{+}$which distinguishes between inactive (11 patients in the group studied), mildly active (29 patients), moderately active (16 patients), and severely active (four patients) disease. The details of this index are shown in Table 1. Its derivation has been discussed previously. ${ }^{5}$ The patients were also subdivided

Table 1 Scheme for grading disease activity in SLE

\section{Criteria for grading clinical severity of SLE}

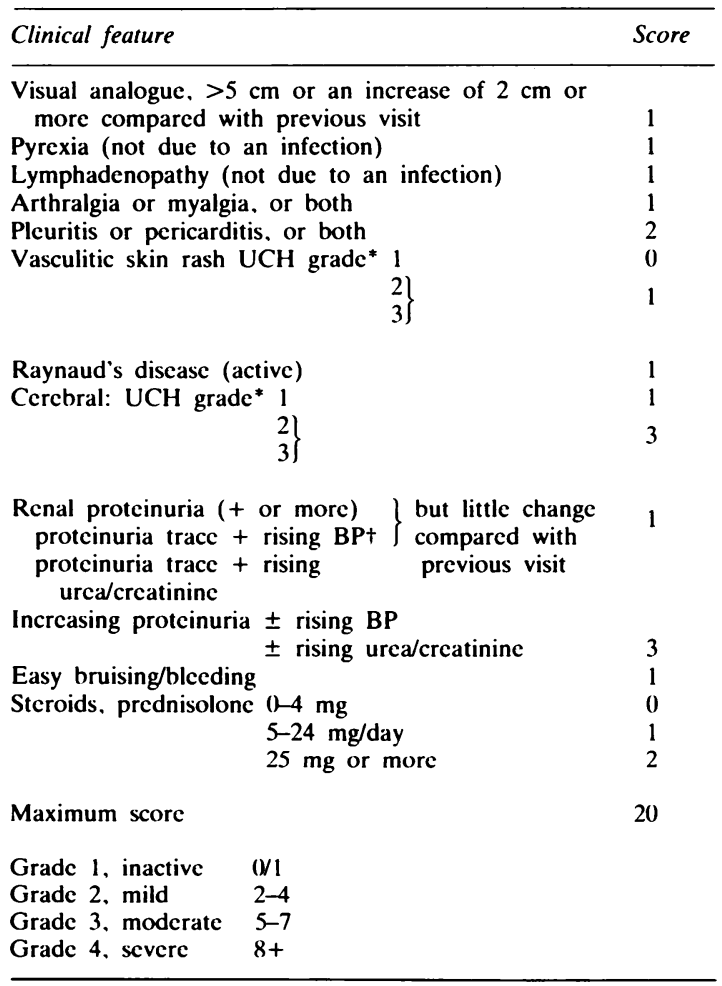

${ }^{*}$ Sec reference 6 for details.

$+\mathrm{BP}=$ blood pressurc. according to their predominant, historical, and clinical manifestations. Thus of the 60 patients with SLE, $56(93 \%)$ had arthralgia; $46(77 \%)$ had a skin rash, of whom 21 had a history of photosensitivity; $19(32 \%)$ had renal disease; $20(33 \%)$ had cerebral involvement; $11(18 \%)$ had thrombocytopenia; and $35(58 \%)$ had pleuritis with or without pericarditis. The definitions used for renal and central nervous system involvement and thrombocytopenia have been published elsewhere. ${ }^{6}$

Thirty sera were taken from patients with classical or definite rheumatoid arthritis (21 female, nine male, age range $24-80) .{ }^{7}$ Sera from 10 patients each with primary Sjögren's syndrome (eight female, two male, age range 24-72), myositis (seven female, three male, age range $22-50$ ), scleroderma (nine female, one male, age range 24-72), and autoimmune liver disease (five female, and five male, age range 34-64) were also studied. The patients with Sjögren's disease were diagnosed according to the published criteria of Isenberg et al $l^{8}$; those with myositis met three or more of the criteria of Bohan and Peter'; those with scleroderma met the preliminary criteria of the American Rheumatism Association ${ }^{10}$; and those with chronic biliary cirrhosis or chronic active hepatitis were diagnosed histologically after liver biopsy. Sera from 70 individuals were used to provide a normal control population for the non-commercial assays. These individuals were healthy blood bank donors, patients attending a rheumatology clinic with 'soft tissue' lesions only, or healthy volunteers who did not work in a hospital or laboratory (53 female, 17 male, age range 23-87). Most patients and controls were Caucasian, many of the remainder coming from the West Indies, India, or South East Asia. The only exception to this was the group with autoimmune liver disease, all of whom were Caucasian.

DETECTION OF ANTI-SSDNA AND ANTIdsDNA ANTIBODIES BY ELISA

Ninety six well polystyrene ELISA plates (Immulon 2, Dynatech, Billinghurst, Sussex) were precoated with $50 \mu \mathrm{l}$ of poly-L-lysine (Sigma, Poole, Dorset) $(50 \mu \mathrm{g} / \mathrm{ml}$ in distilled water) and incubated for one hour at $37^{\circ} \mathrm{C}$. Each well was then washed three times with phosphate buffered saline (PBS) (Flow, Ayrshire, Scotland) before the addition of $50 \mu \mathrm{l}$ of dsDNA $(10 \mu \mathrm{g} / \mathrm{ml})$ or ssDNA $(5 \mu \mathrm{g} / \mathrm{ml})$, both in PBS. The dsDNA was prepared by treating calf thymus DNA (Sigma) with $1 \mathrm{U} / \mu \mathrm{g}$ S1 nuclease (Sigma) for 30 minutes at $37^{\circ} \mathrm{C}$. The ssDNA was prepared by boiling calf thymus DNA for 10 minutes and cooling on ice for 15 minutes. After overnight incubation at $4^{\circ} \mathrm{C}$ the plates were washed three times with PBS. These were then treated with $100 \mu$ l of 
$2 \%$ casein (BDH, Dagenham, Essex) in PBS to prevent non-specific binding, incubated for one hour at $37^{\circ} \mathrm{C}$, and then washed three times with PBS- $0.1 \%$ Tween (PBS-T) (Sigma). Test serum samples were diluted $1 / 200$ in PBS-T and $50 \mu \mathrm{l}$ aliquots were added to the wells in duplicate. A known high positive serum and sera from eight healthy individuals were included on each plate. After overnight incubation at $4^{\circ} \mathrm{C}$ the plates were washed three times with PBS-T. A $50 \mu$ l aliquot of either alkaline phosphatase conjugated goat antihuman IgM or IgG (Sigma), both diluted 1/1000 in PBS-T $/ 0.5 \%$ casein, was then added. Incubation was carried out at $37^{\circ} \mathrm{C}$ for one hour and after washing six times with PBS-T $50 \mu$ l of substrate, $p$-nitrophenyl phosphate disodium (Sigma) in $50 \mathrm{mM}$ carbonate buffer, $\mathrm{pH} 9.3$, containing $2 \mathrm{mM}$ $\mathrm{Mg}^{++}$was added to the plate.

The reaction was allowed to proceed for one hour at $37^{\circ} \mathrm{C}$ and the resulting colour change was recorded at an absorbance of $410 \mathrm{~nm}$ with a Dynatech MR600 ELISA reader. The values obtained were expressed as a percentage of the known high positive value. The normal range was established using the 70 healthy individuals. The upper limit of normal for IgM antibodies to ssDNA was set at $10 \%$; that for IgG antibodies to ssDNA at $20 \%$; for IgM antibodies to dsDNA at $10 \%$; and for IgG antibodies to dsDNA at $12 \%$. In each case the figure represents greater than $2 \mathrm{SD}$ above the mean for the 70 healthy controls.

MILLIPORE FILTER ASSAYFOR dSDNA DETECTION (RIA NCF)

The Millipore filter assay (RIA NCF) used to detect dsDNA binding by sera from patients with SLE is a modification of the methods described in 1973 by Kredich et al ${ }^{11}$ and Ginsberg and Keiser. ${ }^{12}$ $\left[{ }^{3} \mathrm{H}\right]$ Thymidine labelled DNA (NEN, Dupont, UK) was prepared and treated with ribonuclease (Sigma) and S1 nuclease (Sigma) to yield high molecular weight DNA of specific activity $10 \cdot 6 \mathrm{kBq} / \mu \mathrm{g}$. Before use the DNA was passed through a $0.45 \mu \mathrm{m}$ nitrocellulose Millipore filter (Millipore Corp, Massachusetts) and its concentration adjusted to give a cpm rate of about $5000 / 10 \mu$ l DNA corresponding to $0.02 \mu \mathrm{g}$ DNA $/ 10 \mu \mathrm{l}$. The DNA was stored at $4^{\circ} \mathrm{C}$ and used within 24 hours.

Test and control sera were heat inactivated at $56^{\circ} \mathrm{C}$ for 60 minutes and subsequently diluted to a final concentration of $1 / 1000$ in $10 \mathrm{mM}$ TRIS (trometamol) buffer saline pH 7.6 (Sigma). A $90 \mu \mathrm{l}$ aliquot of diluted sera was put into a prewetted Millipore $0.45 \mu \mathrm{m}$ filter bottom 96 well millititre plate (STHA 09610, Millipore Corp). The plate and sera were allowed to equilibrate to $37^{\circ} \mathrm{C}$.
Radiolabelled DNA ( $10 \mu \mathrm{l})$ was added to each we and the plate incubated at $37^{\circ} \mathrm{C}$ for exactly 10 : minutes. The reaction was terminated by placing the millititre plate upon the Millipore vacuum manifor (XX28 09600 ) and applying a vacuum to filter the contents of each well through the $0.45 \mu \mathrm{m}$ mems brane bonded to its base. Each well was washes through with a total volume of $1.0 \mathrm{ml}$ of $10 \mathrm{mis}$ TRIS buffer saline $\mathrm{pH} 7 \cdot 6$ to remove any unbound radiolabelled DNA. The millititre plates were dried at $37^{\circ} \mathrm{C}$ for one hour and the filters punched outo The nitrocellulose filters were cleared in liquiep scintillant fluid Otiphase MB (LKB, UK) ang counted in a beta counter. Using the appropriate controls the total amount of DNA bound was calculated and expressed as $\mu \mathrm{g}$ DNA bound $/ \mathrm{ml}$ of neat sera. The upper limit of normal for this assaces was set at $4.5 \mu \mathrm{g}$ DNA bound $/ \mathrm{ml}$ serum. Th $\xi$ represents a figure greater than $3 \mathrm{SD}$ above the mean for 30 of the healthy individuals selected at randons It should be noted that the use of the 96 we millititre plate allowed the screening of a large number of duplicate samples under identical cones ditions and minimised radioactive contamination by 'containing' the reaction and filtration vessel in the same disposable 96 well plate.

\section{RIA (UK) METHOD}

The gamma-B anti-dsDNA kit enables the measure ment of antibodies in patient serum by measurin the free dsDNA binding capacity in the sample. The method used consists of a modified Farr technique incorporating a tracer which is a circular form of dsDNA manufactured from calf thymus. The manow facturing process of the tracer includes a chromat $\bar{Q}$ graphic step which separates single stranded fro double stranded DNA. Double stranded DNA then tested by S1 nuclease hydrolysis. ${ }^{13}$ More the 15 weeks' storage at $2-8^{\circ} \mathrm{C}$ has not been found cause any significant denaturing of ${ }^{125} \mathrm{I}$ labelle dsDNA into labelled ssDNA. The circular tracer the main difference between the gamma-B and the Amersham Farr method (see later).

Serum from the patients was first heat treated at $56^{\circ} \mathrm{C}$ for 30 minutes to inactivate the non-specifies binding proteins. Double stranded DNA labelled with ${ }^{125} \mathrm{I}(500 \mu \mathrm{l})$ was added to the sample $(50 \mu \bar{\oplus})$ and after incubation at $37^{\circ} \mathrm{C}$ for 15 minutes the antibody bound $\left[{ }^{125} \mathrm{I}\right] \mathrm{dsDNA}$ was separated from the free $\left[{ }^{125} I\right]$ dsDNA by ammonium sulphate precipitation $(500 \mu \mathrm{l}$ saturated solution). After centrp fugation the radioactivity of the dsDNA antibo\& complex in the precipitate was counted for 9 seconds and the results calculated by comparis with a standard curve. The upper limit of normal was set at $5 \mathrm{mg} / \mathrm{l}$. 
CRITHIDIA LUCILIAE DETERMINATION

Test sera diluted to 1:5 in PBS were dropped onto the spots of Crithidia luciliae fixed to microscope slides (Associated Hospital Supplied, Pershore). They were incubated for 15 minutes at room temperature, washed with PBS for 15 minutes, and then a fluorescent antihuman immunoglobulin (Behring, Hounslow) was added and the slide was reincubated for a further 15 minutes. After a further washing step with PBS the slides were mounted in glycerin and $10 \%$ PBS and examined under the fluorescence microscope. They were scored as follows: 0 (no staining); 1 (weak staining); 2 (moderate); or 3 (strong).

\section{STATISTICAL METHODS}

The Kolmogorov-Smirnov test showed that the data were not normally distributed. Thus for the various clinical groups values for each of the assays were compared using non-parametric tests; a MannWhitney $U$ test for comparing two groups and a Kruskal-Wallis one way analysis of variance for more than two groups. Various methods of pooling the data were used, for example grouping together all the lupus cases and comparing all the other non-lupus cases. Essentially, these tests, by comparing the mean rank of the groups tested, are unbiased by the presence of those very large values which were observed in the data. The assays were also tested by establishing contingency tables for values within and outside 'normal' limits for various groups, and tested using a $\chi^{2}$ test, with a correction for small numbers where appropriate. Spearman rank coefficients were determined to compare the values obtained in each of the assays.

\section{Results}

The results of the four ELISA, three RIA, and the Crithidia luciliae immunofluorescence test have been analysed in several ways. In Table 2 the number of sera with raised DNA antibody levels in the SLE and disease control groups is shown. All of the assays showed strong statistically significant differences between the SLE and the combined nonSLE patients $(p<0 \cdot 01)$. Although the Crithidia luciliae test was the most selective, no 'false' positives being found in any of the control groups, it was also the least sensitive as only $13 \%$ of the patients with SLE were positive. In contrast, the RIA (UK) identified $57 \%$ of the patients with SLE but also gave a slightly higher number of 'false' positives amongst the disease controls $(10 \%)$. Of the other tests, the clearest separation between SLE and combined non-lupus groups was found with the anti-dsDNA IgG ELISA $(33 \% v 4 \%)$ and the Amersham kit $(38 \% v 3 \%)$. Analysis of the subgroups is hampered by the relatively small numbers of patients $(n=10)$ with primary Sjögren's syndrome, myositis, scleroderma, and autoimmune liver disease. In the group with rheumatoid arthritis $(n=30)$ all the DNA binding assays distinguished between SLE and RA $(p<0 \cdot 05)$. The assays with the fewest 'false' positives were the Crithidia luciliae and Amersham kit. In contrast, the disease control most likely to have raised DNA binding was the autoimmune liver disease group.

As might be expected those patients whose sera gave positive results in one assay were not necessarily positive in all the other tests. We therefore determined how many patients had raised IgM or IgG dsDNA antibodies, or both, by ELISA (62\%)

Table 2 Comparison of the number of sera with raised DNA antibody levels in the SLE and disease control groups

\begin{tabular}{|c|c|c|c|c|c|c|c|c|}
\hline & \multicolumn{4}{|l|}{$E L I S A$} & \multicolumn{3}{|l|}{$R I A$} & \multirow{2}{*}{$\begin{array}{l}\text { Crithidia } \\
\text { test } \\
\text { No }(\%)\end{array}$} \\
\hline & $\begin{array}{l}\text { ss } \lg M \\
\text { No }(\%)\end{array}$ & $\begin{array}{l}\text { ss } \lg G \\
\text { No }(\%)\end{array}$ & $\begin{array}{l}d s \quad \lg M \\
\text { No }(\%)\end{array}$ & $\begin{array}{l}d s \lg (j \\
\text { No }(\%)\end{array}$ & $\begin{array}{l}R I A(U K) \\
\text { No }(\%)\end{array}$ & $\begin{array}{l}R I A(N C F) \\
\text { No }(\%)\end{array}$ & $\begin{array}{l}\text { Amershain kit } \\
\text { No }(\%)\end{array}$ & \\
\hline SLE $(n=6())$ & $15(25)$ & $19(32)$ & $22(37)$ & $20(33)$ & $34(57)$ & $17(28)$ & $23(38)$ & $8(13)$ \\
\hline \multirow[t]{2}{*}{$\operatorname{RA}(n=3())$} & $*$ & 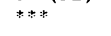 & 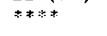 & $* \neq+\infty$ & $+x+4$ & $\neq \neq *$ & $\approx * *$ & $\div$ \\
\hline & $2(7)$ & $1(3)$ & $1(3)$ & $1(3)$ & () (1) & $1(3)$ & $1(3)$ & $0(0)$ \\
\hline $\begin{array}{l}\text { Primary Sjögren`s } \\
\text { syndrome }(n=l())\end{array}$ & $1(10)$ & $2(20)$ & $1(1(1)$ & $0(0)$ & $2(20)$ & () (0) & $1(10)$ & () (1) \\
\hline \multirow[t]{2}{*}{ Myositis $(n=10)$} & NS & * & NS & NS & $*$ & NS & $* *$ & NS \\
\hline & $1(10)$ & $0(0)$ & $2(20)$ & $1(10)$ & $2(20)$ & () (1) & $0(0)$ & () (0) \\
\hline \multirow{2}{*}{$\begin{array}{l}\text { Scleroderma } \\
\qquad(n=1())\end{array}$} & NS & $*$ & NS & $*$ & NS & NS & $\neq$ & NS \\
\hline & $1(10)$ & () (1) & $1(10)$ & () (0) & $3(30)$ & () (1) & () (1)) & () $(0)$ \\
\hline \multirow{2}{*}{$\begin{array}{l}\text { Autoimmune liver } \\
\text { discasc }(n=l())\end{array}$} & NS & NS & NS & NS & $\geqslant *$ & NS & $\because *$ & NS \\
\hline & $1(10)$ & $1(10)$ & $2(20)$ & $1(10)$ & I (I(1) & $2(20)$ & () (1) & () (1) \\
\hline $\begin{array}{l}\text { All non-SLE } \\
\text { discasc controls } \\
(n=7())\end{array}$ & $* * ;$ & w: $x:$ & $* * * *$ & 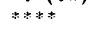 & 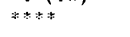 & **** & 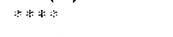 & $\neq * *$ \\
\hline
\end{tabular}

${ }^{*} \mathrm{p}<(1) \cdot\left(15 ;{ }^{* *} \mathrm{p}<(1) \cdot\left(12 ;{ }^{* * *} \mathrm{p}<(1) \cdot() 1:{ }^{* * * *} \mathrm{p}<() \cdot(0) 1\right.\right.$, by $\chi^{2}$ comparing each control group with the SLE group. NS=not significant. 
452 Isenberg, Dudeney, Williams, Addison, Charles, Clarke, Todd-Pokropek

Table 3 Distribution of raised antibodies to DNA by the various techniques compared with the lupus clinical activity inde

\begin{tabular}{|c|c|c|c|c|c|c|c|c|}
\hline & \multicolumn{4}{|l|}{ ELISA } & \multicolumn{3}{|l|}{$R I A$} & Crithidid \\
\hline & $\begin{array}{l}\text { ss } \lg M \\
\text { No }(\%)\end{array}$ & $\begin{array}{l}\text { ss } \lg G \\
\text { No }(\%)\end{array}$ & $\begin{array}{l}\text { ds } \operatorname{Ig} M \\
\text { No }(\%)\end{array}$ & $\begin{array}{l}d s \quad \operatorname{Ig} G \\
\text { No }(\%)\end{array}$ & $\begin{array}{l}R I A(U K) \\
\text { No }(\%)\end{array}$ & $\begin{array}{l}R I A(N C F) \\
\text { No }(\%)\end{array}$ & $\begin{array}{l}\text { Amersham kit } \\
\text { No }(\%)\end{array}$ & No $1 \%) \frac{\bar{c}}{\bar{\omega}}$ \\
\hline Inactive $(\mathrm{n}=11)$ & $3(27)$ & $2(18)$ & $6(54)$ & $4(36)$ & $8(73)$ & $1(9)$ & $3(27)$ & $1(9)$ \\
\hline $\begin{array}{l}\text { Mildly active }(n=29) \\
\text { Moderately active }\end{array}$ & $9(31)$ & $11(38)$ & $12(41)$ & $8(27)$ & $15(52)$ & $9(31)$ & $9(31)$ & $1(3)$ \\
\hline $\begin{array}{l}\text { Moderately active } \\
\quad(n=16) \\
\text { Severely active }\end{array}$ & $1(6)$ & $3(19)$ & $3(19)$ & $4(25)$ & $7(44)$ & $3(19)$ & $7(44)$ & $2(13)$ \\
\hline$(n=4)$ & $2(50)$ & $3(75)$ & $1(25)$ & $4(100)$ & $4(100)$ & $4(100)$ & $4(100)$ & $4(100)$ \\
\hline
\end{tabular}

and compared this with the number with raised dsDNA antibodies by any of the three RIA $(65 \%)$. The difference was not statistically significant.

An analysis of the distribution of sera with raised antibodies to DNA by the various assays, in relation to lupus clinical activity, is shown in Table 3. Several points emerge from this table. Firstly, in the severely active group all three RIA, the anti-dsDNA IgG ELISA, and the Crithidia luciliae test were positive in each of the four cases. Secondly, even in clinically inactive disease raised anti-DNA activity could be shown with all of the assays (including the
Crithidia luciliae test). It was notable, however, that the RIA (UK) levels were raised in $50 \%$ of those $1:$. inactive cases; in contrast, the RIA (NCF) an 8 Crithidia luciliae tests showed levels raised in on one case. Finally, it was apparent that only the Amersham kit showed a progressive increase in the number of sera with raised DNA binding as disease exacerbated.

The results of the non-parametric tests studyino the rank mean values are shown in Tables 4 and 5 . In Table 4 the SLE and disease control groups werg best distinguished by the IgG anti-ssDNA and ant

Table 4 Comparison of the patients with SLE and the disease controls for each test, using the Mann-Whitney $U$ test

\begin{tabular}{|c|c|c|c|c|c|c|}
\hline Test & $\begin{array}{l}S L E v \\
\text { all other } \\
\text { diseases }\end{array}$ & $\begin{array}{l}\text { SLE v } \\
R A\end{array}$ & $\begin{array}{l}S L E \text { v } \\
\text { primary } \\
\text { Sjögren's } \\
\text { syndrome }\end{array}$ & $\begin{array}{l}\text { SLE v } \\
\text { myositis }\end{array}$ & $\begin{array}{l}\text { SLE V } \\
\text { scleroderma }\end{array}$ & $\begin{array}{l}S L E \\
\text { autoimmune } \\
\text { liver disease }\end{array}$ \\
\hline ss IgM (ELISA) & NS* & NS & NS & NS & NS & NS \\
\hline ss IgG (ELISA) & $<0 \cdot(0000) 1$ & $0.0(0) 5$ & $0 \cdot 03$ & $0 \cdot(0) 5$ & $0 \cdot(x) 1$ & NS \\
\hline ds IgM (ELISA) & NS & NS & NS & NS & $0 \cdot(049$ & NS \\
\hline ds $\operatorname{lgG}$ (ELISA) & $(0 \cdot 0001$ & $0 \cdot(0004$ & $0 \cdot 01$ & $0 \cdot() 2$ & 0.05 & NS \\
\hline RIA (UK) & $<0 \cdot 0001$ & $<0 \cdot 0001$ & NS & $0 \cdot() 2$ & 0.03 & NS \\
\hline RIA (NCF) & NS & NS & NS & NS & NS & NS \\
\hline Amersham kit & $<0 \cdot(0001$ & $<0 \cdot(0) 001$ & NS & $0 \cdot(04$ & $0 .(14$ & $(0 \cdot() 4$ \\
\hline Crithidia test & 0.001 & $0 \cdot(03$ & NS & NS & NS & NS \\
\hline
\end{tabular}

${ }^{*} \mathrm{p}$ Values shown in the table.

Table 5 Comparison of the clinical subsets of SLE for each of the assays studied (Mann-Whitney and Kruskal-Wallis test.N0

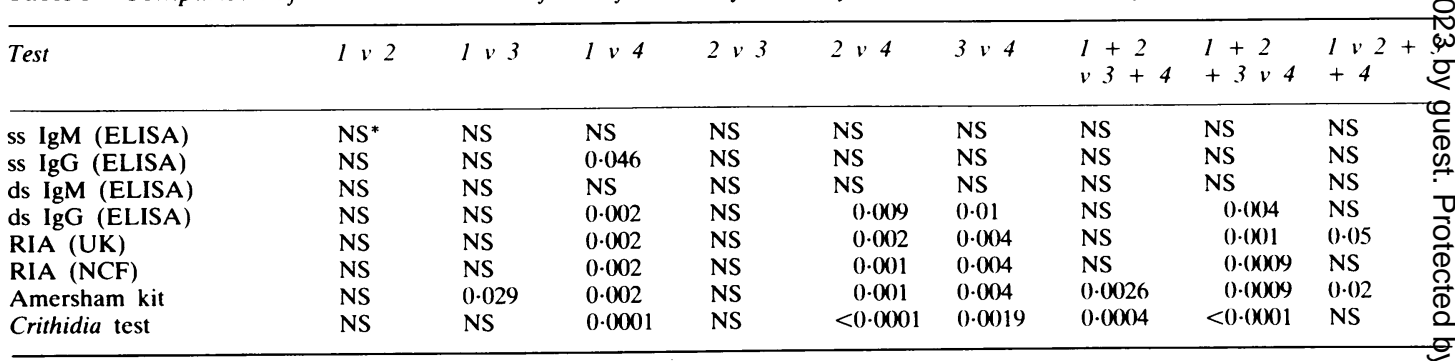

${ }^{*} p$ Values shown in the table. 
Table 6 Comparison of absolute values between the different assays using the Spearman correlation coefficient

\begin{tabular}{|c|c|c|c|c|c|c|c|}
\hline \multirow[t]{2}{*}{ Test } & \multicolumn{4}{|l|}{ ELISA } & \multicolumn{3}{|l|}{$R I A$} \\
\hline & ss $\lg M$ & ss $\lg G$ & ds IgM & $d s \operatorname{Ig} G$ & $R I A(U K)$ & $R I A(N C F)$ & $\begin{array}{l}\text { Amersham } \\
\text { kit }\end{array}$ \\
\hline ss IgG (ELISA) & $\begin{array}{l}r=0.33 \\
p<0.0001\end{array}$ & - & - & - & - & - & - \\
\hline ds IgM (ELISA) & $\begin{array}{l}r=0.38 \\
p<0.0001\end{array}$ & $\begin{array}{l}r=0.21 \\
p<0.008\end{array}$ & - & - & - & - & - \\
\hline ds IgG (ELISA) & $\begin{array}{l}r=0.32 \\
p<0.0001\end{array}$ & $\begin{array}{l}r=0.54 \\
p<0.0001\end{array}$ & $\begin{array}{l}r=0.08 \\
N S\end{array}$ & - & - & - & - \\
\hline RIA (UK) & $\begin{array}{l}r=0.29 \\
p=0.0001\end{array}$ & $\begin{array}{l}r=0.51 \\
p<0.001\end{array}$ & $\begin{array}{l}r=0.30 \\
p=0.0001\end{array}$ & $\begin{array}{l}r=0.33 \\
p<0.0001\end{array}$ & - & - & - \\
\hline RIA (NCF) & $\begin{array}{l}r=0 \cdot 16 \\
\text { NS }\end{array}$ & $\begin{array}{l}r=0.22 \\
p<0.007\end{array}$ & $\begin{array}{l}r=0.07 \\
\text { NS }\end{array}$ & $\begin{array}{l}r=0 \cdot 13 \\
\text { NS }\end{array}$ & $\begin{array}{l}r=0.28 \\
p=0.001\end{array}$ & - & - \\
\hline Amersham kit & $\begin{array}{l}r=0 \cdot 12 \\
\text { NS }\end{array}$ & $\begin{array}{l}r=0.23 \\
p=0.005\end{array}$ & $\begin{array}{l}r=-0.03 \\
N S\end{array}$ & $\begin{array}{l}r=0.15 \\
p=0.04\end{array}$ & $\begin{array}{l}r=0.49 \\
p=<0.0001\end{array}$ & $\begin{array}{l}r=0.31 \\
p<0.0001\end{array}$ & - \\
\hline Crithidia test & $\begin{array}{l}r=0 \cdot 17 \\
\text { NS }\end{array}$ & $\begin{array}{l}r=0.27 \\
N S\end{array}$ & $\begin{array}{l}r=0.01 \\
\text { NS }\end{array}$ & $\begin{array}{l}r=0.31 \\
\mathrm{p}<0.0001\end{array}$ & $\begin{array}{l}r=0.35 \\
p=0.0001\end{array}$ & $\begin{array}{l}r=0.29 \\
p=0.001\end{array}$ & $\begin{array}{l}r=0.38 \\
p<0.001\end{array}$ \\
\hline
\end{tabular}

dsDNA ELISAs, the RIA (UK), and the Amersham kit. This applied both to the control group as a whole and when split into the subgroups. The IgM anti-ssDNA ELISA and the RIA (NCF) were unable to distinguish between the SLE and non-SLE groups by this technique.

The analysis in Table 5 demonstrates the differences between the means for each assay with respect to the clinical activity index. It is evident that the severely ill patients form distinct groups and that good guides to clinical activity are the IgG antidsDNA ELISA, RIA (UK), RIA (NCF), the Amersham kit, and the Crithidia luciliae test.

A comparison of the absolute values obtained in each assay is shown in Table 6 . The best correlations obtained ( $r$ values greater than 0.5 ) were between IgG anti-ssDNA and anti-dsDNA (both by ELISA) and anti-ssDNA and the RIA (UK). In contrast, the ELISA IgM anti-ssDNA and anti-dsDNA were the assays with the fewest number of significant correlations.

Analysis of the lupus patients by subdividing them into those with and without the major clinical features listed in the 'Patients' section, showed few statistically significant correlations with the various assay methods. Anti-dsDNA antibodies measured by ELISA correlated with photosensitive skin rash $(p=0.009)$, and, similarly, the RIA (UK), Amersham kit, and Crithidia luciliae assays were significantly associated with renal disease $(p=0 \cdot 01$, $p=0.002$, and $p=0.003$ respectively).

\section{Discussion}

The simultaneous description by several laboratories almost thirty years ago of anti-DNA antibodies in the serum of lupus patients ${ }^{1+-17}$ has generated a wide ranging debate about their relevance to the pathogenesis of SLE and the utility of their detection. In this study we have attempted to reassess methods used to measure anti-DNA antibodies, not least because of the discrepancies reported by the International Workshop in 1976. ${ }^{\prime}$ This workshop made use of both commercially available assays and more research orientated techniques, as we have done. At the workshop 12 participating centres tested sera from eight patients using up to six different assays, including Farr and Millipore filter binding assays, RIA using a second antibody, and immunofluorescence assays. As was noted, 'on no serum was there total agreement between all the assays performed'. The serum from the patient with the most active lupus (patient No 6), who also had the highest DNA binding recorded in the original referral centre, gave very high levels in most of the assays used. It was surprising that many assays recorded high values in the pooled normal serum and the serum from patients with inactive lupus.

Although an ELISA which could be used to determine antibodies to dsDNA had been described by the time of the workshop, ${ }^{18}$ this technique was not included in the study. An ELISA, however, does offer several potential advantages. It avoids problems of radioactive contamination and disposal, should not be affected by non-immunoglobulin serum components which can bind DNA, is easily measurable, and can be used to distinguish between the different isotypes of DNA antibodies. It has been suggested more recently that the ELISA technique is more sensitive than the immunofluorescent Crithidia luciliae assay, haemagglutination, and fluid phase radioimmunoassays. ${ }^{19} 20$ 
As Stollar has discussed, ${ }^{2}$ the measurement of anti-dsDNA antibodies is dependent upon numerous variables, including the purity of the test antigen, the distinction between binding by antibodies and non-immunoglobulin proteins, and the isotype of the antibody and its functional properties, including its complement fixing ability. This final point has been re-emphasised by Mackworth-Young and colleagues, who found that $46 \%$ of 48 patients with SLE had complement fixing antibodies to dsDNA and that these antibodies were statistically significantly associated with renal disease. ${ }^{21} \mathrm{Al}$ though this observation is in agreement with some previously published studies, $22-24$ other authors, notably Ballou and Kushner, ${ }^{25}$ have concluded that complement fixing anti-dsDNA antibodies could not be related to renal disease independently of the antidsDNA antibody titre. This latter observation is strongly supported by Esparza and colleagues who compared matched sera from patients with and without nephritis, whose anti-dsDNA antibody titre was similar, and found no difference in complement fixation. ${ }^{26}$

The ability to distinguish degrees of avidity among anti-DNA antibodies also varies with different assays. Anti-DNA antibodies of low avidity are not properly detected by the Farr assay, which was introduced in $1968,{ }^{27}$ owing to the dissociating reaction conditions of the ammonium sulphate precipitation step used in this technique. ${ }^{28}$ In contrast, ELISA and the Crithidia luciliae assay can theoretically detect antibodies of low avidity. In addition, an assay introduced by Smeenk and colleagues using polyethylene glycol precipitation (PEG) can also detect low avidity antibodies. ${ }^{29}$ Unlike the ELISA and Crithidia luciliae tests the PEG assay does not incorporate an intrinsic check on the immunoglobulin nature of what is binding to the test DNA (i.e., as the second step, antihuman immunoglobulin used). The importance of this check probably also explains the fact that Smeenk and colleagues, when devising their own anti-DNA ELISA, found that it made little difference whether or not the plates were coated with the circular, PM2 bacteriophage derived DNA or calf thymus DNA, ${ }^{28}$ even though the latter is known to contain single stranded DNA regions.

Since the assays described in our own and other studies clearly differ in their ability to reflect the parameters discussed above it is not surprising that individual sera sometimes reacted quite differently in the various tests. This type of discrepancy is widely recognised, ${ }^{2} 3031$ and our finding of increased numbers of positive sera with the ELISA compared with the modified Farr assays is not surprising in view of the latter's failure to detect low avidity antibodies. Previous authors have showion that the assay using Crithidia luciliae is also more sensitive than Farr assays. For example Smeenk et a a state that only $39 \%$ of their Crithidia positive ser were also positive in the Farr assay. ${ }^{29}$ In contrast, o $\underline{\underline{\underline{Q}}}$ the Farr positive sera, $68 \%$ were Crithidia positive We do not know why relatively few of our SLED patients were positive in the Crithidia test, though we suspect, as discussed later, that patient selectionis important.

Eilat has reviewed some of the available assays $3 \overrightarrow{\vec{\omega}}$ and this has reinforced concern that although solies phase assays are likely to be more sensitive thar ammonium sulphate and filter assays, this sensitivity is achieved by simply detecting antibodies witlo lower affinity. The ELISA results reported by Eaton et $a l^{33}$ could be interpreted as supporting this view In their study of 154 lupus sera these authors foun $\mathbb{Q}$ that $94 \%$ of patients with active SLE and $70 \%$ of sera from patients with inactive disease were posic tive, as were $2.5 \%$ of normal persons. This matche a similar analysis of 141 patients using an ELISA method, ${ }^{19}$ which found that $85 \%$ (active and inacer tive) were positive for anti-DNA antibodies, as were $3.3 \%$ of 268 normal sera tested. In contrast, our ow results showed a much lower number of positive sers by both ELISA $(25-37 \%)$ and RIA $(28-57 \%)$ Furthermore, the similarity in the results between the RIA (NCF) and IgG anti-dsDNA ELISA, fo $\mathbb{2}$ example, suggests that there is little difference i $\overrightarrow{\vec{b}}$ the utility of detection by these very different tech 3 niques. The variation in the ELISA results of oug study and those of previous reports may reflec $\overrightarrow{\text { P. }}$ methodological differences or variation in the lupus populations studied, or both.

The question of patient selection must be con sidered. In the past most authors have stressed the links between raised anti-dsDNA antibody levels and renal disease in SLE. ${ }^{34}{ }^{35}$ Our department has primary rheumatological interests and our lupus referrals undoubtedly reflect this. We are thus les likely to see patients who present with major renat. problems, and this is probably why in our group lesల్ than one third were deemed to have major renal involvement. This in turn may explain why the tota numbers of patients with SLE in this study witko raised dsDNA binding are relatively low in many of the assays. In addition, since the bulk of our patiente are outpatients, most sera studied were fror patients considered to have inactive or mildly active disease only. If the IgG and IgM ELISA, or a three RIA are combined, however, the number of patients with high dsDNA levels are increase to over $60 \%$. In addition, our serial studies ( noß described here) further increase the numbers to ove $80 \%$. 
The clinical activity index that we have used attempts to provide a detailed overall assessment of the lupus patient. Many previous reports have referred to the patients studied as simply active or inactive, and it is often difficult to determine on what basis this judgment was made. The index may be criticised on the grounds that it has not been independently assessed, but this is currently being addressed by the British Isles Lupus Assessment Group (BILAG - a group of interested physicians in the Bloomsbury rheumatology department and in the rheumatology departments of Bath, Birmingham, and Glasgow). We believe, however, that the index used is a reasonable attempt to acknowledge the many facets of SLE, which also weights renal and cerebral disease, as these are frequently associated with major morbidity in our experience.

Which then is/are the test(s) to use on a regular basis? The answer clearly depends on several factors including the practical problems of experience in performing the assays and having the equipment to do them, the time involved, and the cost of the commercial kits. Of the commercial kits used in this study, we estimate that the Amersham kit costs approximately $£ 5$ a sample (tested in duplicate) and requires an overnight step; the RIA (UK) costs a little over $£ 4$ a sample (in duplicate) and can be performed on the same day; and the Crithidia luciliae test costs around $£ 5$ a sample and can also be done in a few hours (but is the least sensitive). Of the research assays used, the ELISA in duplicate costs per assay approximately $10 p$ a sample and the RIA (NCF) about 60p. Each department must carefully weigh the variables discussed before deciding which assay(s) to use.

We thank Dan Eilat for advice about the Millipore filter assay and the Millipore Corporation for technical assistance. Dr Ian Barrison kindly supplied a number of the sera.

\section{References}

1 Lachman P J. Detection and measurement of anti-DNA antibodies. Ann Rheum Dis 1977; 36 (suppl): 67-75.

2 Stollar B D. Anti-DNA antibodies. Clin Immunol All 1981; 1: 243-60.

3 Tan E M, Cohen A S, Fries J F, et al. The 1982 revised criteria for the classification of systemic lupus erythematosus. Arthritis Rheum 1982; 25: 1271-7.

4 Isenberg D A. Shoenfeld Y, Schwartz R S. The use of hybridomas to analyse autoimmunity. Br Med Bull 1984; 40: 262-6.

5 Isenberg D A, Shoenfeld Y, Schwartz R S. Multiple serological reactions and their relationship to clinical activity in systemic lupus erythematosus. Arthritis Rheum 1984; 27: 132-8.

6 Morrow W J W. Isenberg D A, Todd-Pokropek A, Parry H F, Snaith M L. Useful laboratory measurements in the diagnosis of systemic lupus erythematosus. $Q J$ Med 1982; 51: 125-38.

7 Ropes M W, Bennett G A, Cobb S, Jacox R, Jessar R A Revision of diagnostic criteria for rheumatoid arthritis. Bull Rheum Dis 1958: 9: 175-6.
8 Isenberg D A, Rowe D, Tookman A, et al. An immunohistological study of secondary Sjögren's syndrome. Ann Rheum Dis 1984; 43: 470-6.

9 Bohan A. Peter J B. Polymyositis and dermatomyositis. N Engl J Med 1975; 292: 344-7.

10 Masi A T, Rodnan G P, Medsger T A, et al. Preliminary criteria for the classification of systemic sclerosis (scleroderma). Bull Rheum Dis 1981; 31: 1-6.

11 Kredich N M, Skyler J S, Foote L J. Antibodies to native DNA in systemic lupus erythematosus. A technique of rapid and quantitative determination. Arch Intern Med 1973; 131: 639-44.

12 Ginsberg B, Keiser H. A Millipore filter assay for antibodies to native DNA in sera of patients with systemic lupus erythematosus. Arthritis Rheum 1973; 16: 199-207.

13 Carperson G F. Voss E W. Colicine E1 plasmid as a probe for the detection and study of anti-DNA antibodies in SLE sera. J Immunol Methods 1980; 36: 293-308.

14 Ceppellini R. Rolli E, Celada F. A DNA-reacting factor in serum of a patient with lupus erythematosus diffusus. Proc SocExp Biol Med 1957; 96: 572-4.

15 Miescher P. Strassle R. New serological methods for the: detection of the LE factor. Vox Sang 1957; 2: 283-7.

16 Kievitis J H. Schuit H R F. A simple indirect LE-cell test with increased sensitivity. Vox Sang 1957; 2: 288-93.

17 Robbins W C, Holman H R, Deicher H, Hunkel H G. Complement fixation with cell nuclei and DNA in lupus erythematosus. Proc Soc Exp Biol Med 1957; 96: 575-9.

18 Engvall E, Perlmann P. Enzyme linked immunosorbent assay. ELISA. 3. Quantitative assay of specific antibodies by enzyme labelled anti-immunoglobulin in antigen coated tubes. J Immunol 1972; 109: 129-35.

19 Halbert S P, Karsh J, Anken M. Studies on autoantibodies to deoxyribonucleic acid and deoxyribonucleoprotein with enzyme immunoassay (ELISA). J Lab Clin Med 1981; 97: 97-111.

20 Miller T E, Lahita R G, Zarro V J, MacWilliam J. Koffler D. Clinical significance of anti-double stranded DNA antibodies detected by a solid phase enzyme immunoassay. Arthritis Rheum 1981: 24: 602-10.

21 Mackworth-Young C G, Chan J K H, Bunn C C, Hughes G R V. Gharavi A E. Complement fixation by anti-dsDNA antibodies in SLE: measurement by radioimmunoassay and relationship with disease activity. Ann Rheum Dis 1986; 45: 314-8.

22 Sontheimer R D, Gilliam J N. DNA antibody class, subclass and complement fixation in systemic lupus erythematosus. Clin Immunol Immunopathol 1978; 10: 459-67.

23 Beaulieu A, Quismorio F K Jr, Kitridou R C, Friou G J. Complement fixing antibodies to dsDNA in SLE: a study using the immunofluorescent Crithidia luciliae method. J Rheumatol 1979; 6: 389-96.

24 Beaulieu A, Quismorio F K Jr, Friou G J, Vayuvegula B, Mirick G. IgG antibodies to double stranded DNA in systemic lupus erythematosus. Independent variation of complement fixing activity and total antibody content. Arthritis Rheum 1979; 22: 565-70.

25 Ballou S P, Kushner I. Immunochemical characteristics of antibodies to DNA in patients with active lupus erythematosus. Clin Exp Immunol 1979; 37: 58-67.

26 Esparza R H, Swaak T, Aarden L, Smeenk R. Complement fixing antibodies to dsDNA detected by the immunofluorescent technique on Crithidia luciliae. A critical appraisal. J Rheumatol 1985; 12: 1109-17.

27 Wold R T, Young F E, Tan E M, Farr R S. Deoxyribonucleic acid antibody, a method to detect its primary interaction with deoxyribonucleic acid. Science 1968; 161: 806-15.

28 Smeenk R. Low avidity antibodies to dsDNA. Amsterdam: Rodolphi, 1982. (PhD dissertation.)

29 Smeenk R, van der Lelij G, Aarden L. Avidity of antibodies to dsDNA: comparison of IFT on Crithidia luciliae, Farr assay, and PEG assay. $J$ Immunol 1982; 128: 73-8. 
456 Isenberg, Dudeney, Williams, Addison, Charles, Clarke, Todd-Pokropek

30 Swaak A J K, Groenwald J, Aarden L A. Feltkamp T E W. Detection of anti dsDNA as diagnostic tool. Am Rheum Dis 1981; 40: 45-9.

31 Somerfield S D, Roberts M W. Booth R J. Double stranded DNA antibodies: a comparison of four methods of detection. $J$ Clin Pathol 1981; 34: 1032-5.

32 Eilat D. Anti-DNA antibodies: problems in their study and interpretation. Clin Exp Immunol 1986: 65: 215-22.
33 Eaton R B. Schnneider G. Schur P H. Enzyme immunoassa for antibodies to native DNA. Arthritis Rheum 1983: 26: 52-62.

34 Pincus T. Schur P H. Rose J A. Decker J L. Talal N Measurement of serum DNA-binding activity in systemic lupus erythematosus. N Engl J Med 1969; 281: 701-5.

35 Swaak A J G. Aarden L A. Statius van Eps L W. Feltkamō T E W. Anti ds-DNA and complement profiles as prognost guides in systemic lupus erythematosus. Arthritis Rheum 197\% 22: $226-35$. 